\title{
Moč odsotnega: eluzivnost resničnosti v dveh Antigonah
}

\section{Brane Senegačnik}

Filozofska fakulteta Univerze v Ljubljani, Oddelek za klasično filologijo, Aškerčeva 2, 1000 Ljubljana https://orcid.org/0000-0002-5182-5657

brane.senegacnik@gmail.com

\begin{abstract}
Kot je dobro znano, bogovi v Sofoklovi Antigoni ne nastopijo (niti prek prerokb), vendar se use $v$ drami zgodi zaradi njih. Njihova avtoriteta ni sporna, a je prav zato, ker so odsotni, nejasna in eluzivna njihova volja: to odpira prostor Antigoni in Kreontu, da jo razlagata na povsem drugačen način, kar sproži njun usodni konflikt. Ko Tejrezias razkrije, da Kreont nima prav, je že prepozno za Antigono, ki je umrla zato, ker je ostala zvesta svojemu (pravilnemu) razumevanju božje volje (postave), čeprav je v tem ni podpirala nobena zunanja avtoriteta, ne božanska, ne človeška. VAntigoni Dominika Smoleta pa je odsotna naslouna junakinja, in to vse do konca drame, ko jo ubijejo in njeno vlogo prevzame Paž. Smoletova radikalna inovacija nenehoma usmerja pozornost bralca (gledalca) v ozadje dramskega dogajanja, v nevidno resničnost onstran odra: $v$ prepovedano območje izven uradne družbe, kjer se postavljajo bistvena vprašanja o zgodovinski resnici in o tem, kaj človek v resnici je. Drami kažeta analogne poteze v dramaturški zgradbi, zlasti pa v predstavljanju resničnosti: ultimativna resničnost (bogovi pri Sofoklu, človekova resnična identiteta) je v obeh prikrita, vendar bistveno učinkuje na življenje: razkriva se kot temno obzorje in ohranja človeško resničnost odprto. Poleg glavne teme razprava razmeroma nadrobno obravnava tudi motive za (literarno in teoretično) reinterpretacijo kanoniziranih besedil.
\end{abstract}

Ključne besede: slovenska dramatika / grška tragedija / Sofokles / Smole, Dominik / Antigona / literarni vplivi / medbesedilnost / etika / ultimativna resničnost

\section{Dominik Smole o Sofoklovi Antigoni}

Avtorji in avtorice niso nujno najboljši interpreti svojih lastnih del, vendar pa povsem mimo njihovih razlag ni smiselno iti. Kar zadeva pobude, motive in zglede za nastanek del, so njihove besede še bolj relevantne. Zlasti pa je zanimivo, če se izkaže, da so v soglasju z interpretacijo, ki je nastala povsem neodvisno od njih, ker jih interpret sploh ni poznal. Za tak primer gre pri tej razpravi, katere glavni namen je pokazati, 
da dve drami, Sofoklova Antigona in istoimensko delo Dominika Smoleta, prikazujeta ultimativno resničnost (in s tem celotno človeško resničnost) na pomembno analogen način. Smoletove besede o njegovem odnosu do Sofoklove tragedije mi niso bile znane, preden sem svoj interpretativni poskus že izoblikoval v vseh bistvenih črtah. Šele ob pripravi besedila razprave sem ugotovil, da je Smole sam poudaril vpliv znamenite antične tragedije na pisanje svoje drame. $V$ teh njegovih besedah sem videl nekakšno vzvratno pritrditev in jih razumem kot dodaten, "zunanji« argument za primernost svojega branja, čeprav avtor ni poznal (in v mnogih primerih niti ni mogel poznati) izhodišč slednjega in večinoma tudi v njem navedenih argumentov ne. A to ni bistveno: bistveno je, da je očitno razmerje njegovega dela s Sofoklovim pomembno in da bi si zaslužilo večjo pozornost literarne vede, kot je je bilo deležno doslej.

Smoletove izjave o Sofoklovi Antigoni bi se sicer med seboj le težko bolj razlikovale. Leta 1960 je Sofoklovo dilemo - sicer Kreont ali Antigona - označil kot nezadostno za razmere sodobne zgodovine in zatrdil, da ni bila povod za pisanje njegove drame (Smole, "Nevezan pogovor « 252). ${ }^{1}$ Ta kategorična, a kratka, nerazdelana, nekako mimobežna sodba seveda ne spodbuja intertekstualnih raziskovanj. Popolnoma drugače pa je sodil leta 1964 v pogovoru za Borbo, kjer je bilo odnosu do Sofoklovovega dela posvečenih več vprašanj (Smole, "Antigone pobjeđuju« 253-258). Tudi tu sicer pravi, da mu ni šlo za nadaljnje razdelovanje sofoklovskega antagonizma med glavnima likoma, temveč za analizo situacije, ki jo sofoklovska Antigona ustvarja v družbi. Vendar dodaja, da so vse dileme glede izbire med etičnim in etatističnim, humanim in pragmatičnim, smislom in nihilizmom že pri Sofoklu čiste kot sonce. Na vprašanje, kaj ga je pritegnilo prav pri mitu o Antigoni, odgovori v enem stavku: "Naša sodobna družbena situacija" (254). Pravi tudi, da je od drugih Antigon poznal le Sofoklovo, to pa je imel, tako upa, povsem pred očmi pri pisanju svoje drame. Sofoklovo tragedijo je bral in prebral na vse mogoče načine: razlike, do katerih je prišel pri oblikovanju svoje vsebine na to temo, "so popolnoma odvisne od Sofoklovega velikega sporočila" (254). In končno, na vprašanje, zakaj poetična forma, odvrne: „Če se človek že odloči za Antigono, potem mora izbrati stih" (258).

Seganje po temah kanoniziranih del je veliko, izzivalno vprašanje, tako za teorijo intertekstualnosti kot za literarnozgodovinsko razisko-

\footnotetext{
${ }^{1}$ Besedilo Smoletove Antigone, interpretacije, kritiške odzive in intervjuje navajam po ponatisu v drugi in peti knjigi njegovega Zbranega dela (glej Schmidt, Dominik Smole. Zbrano delo. Druga knjiga in Dominik Smole. Zbrano delo. Peta knjiga).
} 
vanje motivov. V primeru intertekstualno tako izjemno živega besedila, kot je Sofoklova Antigona, se mu je težko povsem izogniti. Zato se zdaj za kratko poslavljamo od Smoletove drame, da bi osvetlili nekaj splošnih vidikov motivacije za vzpostavljanje inetertekstualnih navezav na najvplivnejši Sofoklov tekst.

\section{Motivi intertekstualnih navezav na Sofokolovo Antigono}

Vprašanje o motivih za uprizarjanje in pisanje vedno novih Antigon, za nenehno vračanje $\mathrm{h}$ kanoniziranemu prototekstu ${ }^{2}$ se zdi danes tako trivialno, da se ga skorajda ne spodobi zastaviti. Nove uprizoritve in besedila pogosto zbujajo obsežno in raznoliko pozornost kritike in neredko postanejo predmet različnih literarnovednih raziskav, vendar se slednje skoraj praviloma ne dotikajo bistva tega vprašanja, torej motiva, ampak več ali manj opisujejo nove načine obravnave, estetske perspektive in etične vidike sodobnih predelav in se ukvarjajo z njihovo literarnoteoretično klasifikacijo. Morda pa to vprašanje v resnici ni tako trivialno: zakaj res segati po slavnih, kanonskih temah in na njihovi podlagi ustvarjati radikalno samosvoja dela? Gre morda za željo, da bi tematika in dialog s slovitimi kanoniziranimi sogovorniki izborila avtorju čim večji košček prostora pod soncem zgodovinske relevantnosti?

Vprašanje se zdi tem bolj zanimivo, ker so tudi antični tragedi $\mathrm{v}$ ogromni večini primerov dramatizirali in preoblikovali že znane zgodbe, mite, ki so krožili v drugačni "prototekstualni« obliki, namreč v obliki epske poezije. To razmerje je specifično in predstavlja poseben problem zaradi ustne tradicije, v kateri je (dolgo časa najverjetneje ekskluzivno, zagotovo pa v prevladujoči meri) obstajala epska poezija, kar pa je za temo te razprave manj pomembno. ${ }^{3}$ Podobno velja tudi za sekundarna metatekstualna razmerja, oziroma za intertekstualna razmerja med grškimi tragiškimi deli: $v$ mislih imam očitne vplive enega tragiškega dela na drugega. ${ }^{4}$ Poleg tega, da se zastavlja vrsta čisto specifičnih nelahkih

\footnotetext{
${ }^{2}$ Izraz uporabljam v najširšem pomenu »besedila, ki rabi kot objekt intertekstualne kontinuitete« (Popovič 226). Oblike intertekstualnih navezav in razmerij so seveda izredno številne in jih je zaradi nenehnega dinamičnega razvoja težko klasificirati, kar ima za posledico tudi določeno terminološko ohlapnost.

${ }^{3}$ Gregory Nagy upravičeno opozarja na razliko med bralno in slišno recepcijo: medtem ko (antični in sodobni) bralec in kritik razločujeta med izvirnikom in vrivki, pa je za poslušalce rapsod v svojem nastopu utelešal avtorja (pesnika), zato so lahko vse morebitne variacije, izpuste in dodatke sprejemali kot pristno avtorske (Nagy 291-292).

${ }^{4}$ Najbolj ilustrativna primera tega sta prizor v Evripidovi Elektri (verzi 503-546), v katerem je očitna racionalistična kritika anagnorizma v Ajshilovih Prinašalkah pitnih
} 
vprašanj o možnostih in načinih učinkovanja teh intertekstualnih postopkov, ${ }^{5}$ je predvsem očitno, da so bili le-ti vsekakor zamejeni in zaznamovani s pragmatičnim okvirom: $\mathrm{z}$ okvirom, ki je določal njihov namen (obzorje), obliko recepcije in v marsičem tudi njihovo tematiko. Tudi če odmislimo čisto »tehnični«, a nikakor nepomembni, vidik, da grški tragedi niso računali na bralno recepcijo (ki je v sodobnem svetu vsaj praviloma pomembna dopolnilna možnost sprejemanja dramskih besedil), pa nikakor ne moremo mimo dvojega: mimo tega, da sta njihovo dejavnost določala obsežni in razvejani Dionizov kult, v okviru katerega so se uprizarjale tragiške predstave, in - razen v skrajno redkih primerih - mitološka tematika. K temu je treba prišteti še tradicionalno, že vsaj od homerskih časov (8. stoletje) utrjeno prepričanje o pesniku kot moralnem učitelju, ki je $\mathrm{v}$ sicer novem družbenem kontekstu demokratične atenske polis določalo tudi položaj tragiških pesnikov. ${ }^{6}$ Pričakovalo se je torej, da bo tudi tragiška poezija imela vzgojne učinke (kot je dobro znano, so prav s takim pričakovanjem povezane ostre kritike tako epske kot tragiške poezije pri raznih filozofih od Ksenofana in Heraklita do Platona). ${ }^{7}$ Zelo pomemben pragmatični vidik pa je tudi njen institucionalizirani središčni položaj v družbeni strukturi; ta središčnost - ki jo lahko razumemo tako $\mathrm{v}$ fizičnem kot $\mathrm{v}$ simbolnem smislu - je bila seveda vir izrednega političnega, morda je primerneje reči: družbenega vpliva (Croally 63-64). ${ }^{8}$ Zaradi tega okvira, mimo katerega ne more nobena relevantna interpretacija, je grško tragedijo kočljivo povezovati z drugimi historičnimi konteksti, in to velja tudi za umetnost. Zavest o tem okviru je v sodobnem raziskovanju zelo živa; njegove epistemološke koordinate, ki so predvsem historične, kulturne in sociološke, dobro povzema tale opredelitev: „Grški miti na splošno utelešajo in raziskujejo temeljne družbene institucije in $\mathrm{z}$ njimi pove-

darov (verzi 164-243) in pa verjetni vpliv Sofoklove Antigone na predelano različico Ajshilove tragedije Sedmerica proti Tebam (prim. Sommerstein 90-95).

${ }^{5} \mathrm{Za}$ zelo strnjen pregled teh problemov in relevantnih antičnih virov glej Csapo 3-17.

${ }^{6}$ Ta že davno znani in široko sprejeti pogled literarne zgodovine je v novejšem času na zgoščen in svež način artikuliral in utemeljil Neil Croally (Croally 55-70).

7 O Homerju kot učitelju prim. Ksenofan, DK 10; Platon, Država 595b10-c1; 606-607; Ion, Hipija Manjši; o Homerju, Orfeju, Heziodu in tragikih prim. komediograf Aleksis, frg. 140; o pesnikih na splošno prim. Protagora v Platonovem Protagori 316d2-9; prim. tudi Platon, Zakoni 666d-667a, kjer se očitno pričakuje, da bo tragedija poučevala.

${ }^{8}$ Vse 5. stoletje (pa tudi pozneje) tragedijo izvajajo $\mathrm{v}$ Dionizovem gledališču ob vznožju Akropole, kjer so stale vse glavne religiozne zgradbe, v bližini pa je bila tudi agora, središče političnega življenja. 
zana prepričanja in vrednote. Grška tragedija pa še posebej preiskuje te institucije in vrednote tako, da dramatizira trenutke skrajne krize, nasilnih konfliktov in čustvenih pretresov, trenutke, v katerih so tradicionalne vrednote ogrožene, družbene vezi pa pretrgane (Anderson 124). Takšna tematizacija pa tragedijo vendarle reducira: izloča njeno izvorno teološko razsežnost. $\mathrm{V}$ tem pogledu je $\mathrm{v}$ določeni meri analogna bistveno sekularizirani interpretaciji tragedije, ki jo srečamo v Aristotelovi Poetiki. ${ }^{9}$

Ko so torej grške tragedije prestavljene v obzorje literarne zgodovine in jih obravnavamo kot del kanona svetovne književnosti, delujejo bistveno drugače, kot so v svojem izvornem zgodovinskem okolju. Mitične zgodbe, ki so njihovo jedro oziroma počelo, kot bi rekel Aristotel, so neprimerljive $\mathrm{z}$ dramskimi besedili v modernem smislu: miti so bili namreč kljub vsem specifikam grške religije, kljub lastni spremenljivosti in racionalistični kritiki, ki so ji bili izpostavljeni v času sofizma, vseeno "svete zgodbe«, ki so, če že ne določale, pa vsaj barvale mentaliteto in identiteto ljudi tedanjega časa in začrtovale kolektivno in individualno miselno, simbolno, etično, bržčas pa tudi emocionalno obzorje. In ki so bile tesno povezane s kulti. V sekulariziranem obzorju sodobnega sveta pa neizbežno postanejo zgolj dramske, literarne oziroma kulturne reference, ki nimajo enakega, celo primerljivega statusa ne, in to tako zaradi obsega in strukture sodobne družbe kot zaradi drugačne konfiguracije zgoraj omenjenih obzorij. Ta nepresegljiva pragmatična različnost je bolj ali manj trivialno dejstvo, podobno kot so trivialno očitne zunanje tematske, motivne in idejne vzporednice.

Slavna umetniška dela pa lahko ustvarjajo okoli svojega položaja v kulturnem kanonu nekakšna odlikovana prazna mesta: dialog z njimi, predelava, preobrazba, parodija, zgolj globoko zakodirane asociacije in naslovne reference in druge oblike intertekstualnih navezav lahko zagotovijo svojski avtorski prestiž in pomen. Včasih se zdi - in prav Sofoklova Antigona je tak primer -, da ta prazna mesta tako rekoč zahtevajo od družbeno vplivnih piscev, pa najsi bodo pisatelji, filozofi ali intelektualci, da jih zasedejo v svojem času in postanejo skorajda nekakšni reprezentanti tega mitiziranega (a, kot smo videli, nikoli resnično mitičnega) izročila. To dokazuje neverjetna množica neverjetno različnih dramskih in literarnih Antigon kakor tudi intelektualno produktivnih izvajanj pod naslovom interpretacije Sofokolovega teksta. Slednja so še posebej zanimiva: če je namreč pri literarnih besedilih nesporno, da so adaptacije ali celo povsem svobodne variacije

\footnotetext{
${ }^{9}$ Prim. Halliwell 403.
} 
prototeksta, pa se ta (filozofska, psihoanalitična in druga teoretična) izvajanja predstavljajo prav kot avtentična branja Sofoklove Antigone, čeprav je očitno, da včasih niso posebej skrbna, temveč izredno enostranska in da kdaj tudi brezobzirno reducirajo izvirnik ali celo vnašajo vanj docela tujo idejno problematiko. ${ }^{10}$ Vendar to ne zmanjšuje njihove odmevnosti, vsaj ko gre za najvplivnejše avtorje: lahko bi rekli, da se kanonska slava Sofoklovega besedila v teh primerih pomnožuje s slavo interpretov, posledica pa je ekspanzija interpretacijskega prostora, včasih tudi onkraj meja smiselnega. $Z$ vidika literarne teorije je nedvomno vznemirljiva npr. Žižkova Antigona, ki se naslanja, kot pravi avtor, na že obstoječe prevode in jih kombinira z odlomki iz cele vrste žanrsko najrazličnejših besedil in jih na ta način tako estetsko kot zlasti idejno močno preoblikuje. ${ }^{11}$ To nekoliko spominja na humanistično prakso dopolnjevanja rimskih dram, ki se niso ohranile v celoti, čeprav je seveda namen Žižkovih posegov in njegov odnos do prototeksta bistveno drugačen: če so humanisti praviloma skušali ujeti duha izvirnika (in ga le priložnostno »humanizirati«, uskladiti s svojo idealno predstavo o umetnosti antičnih vzornikov), želi Žižek napisati svojo Antigono, ki je nima za umetniško delo, temveč za etično-politično vajo. ${ }^{12}$

Pomembnejši motiv za seganje $\mathrm{k}$ antični tematiki je prepoznavanje analognosti zgodovinskih dogodkov in situacij, ki obeta obenem zastrto in izostreno literarno upodobitev sodobne tematike. Kanonizirana umetniška artikulacija često izzove in osmisli sodobno repliko v tem smislu; vendar je tudi vzpostavljanje takšnih dinamičnih analogij polno

${ }^{10} \mathrm{~S}$ tem mislim zlasti na filozofske interpretacije, ki zgodbo Sofoklove Antigone uglašujejo s svojim ontološkim vzorcem (Hegel) ali iščejo v besedilu potrdilo lastnih ontoloških izvajanj (Heidegger, Uvodv metafiziko in Hölderlins Hymne "Der Ister") ali pa na filozofirajoče interpretacije kot je Lacanova, ki "predstavlja Antigono kot model čiste želje» (Miller 1; prim. Lacan, Etika 241-290). Ta izvajanja so (bila) izjemno vplivna kljub svojim enostranostim in temu, da v marsičem predstavljajo samo duhovit ali ingeniozen interpretativni adýnaton. Če Heidegger občasno zagovarja nemogočo sintakso in pogosto etimološko pretirava, ga daleč presegajo Lacanovo asociativno povezovanje besed, ignoriranje sintaktičnih pravil in preprostih retoričnih figur ter igrivo pretresanje osnovnih slovarskih pomenov, ki ga suvereno prikazuje kot globinsko semantično analizo (zlasti Lacan, Etika 276-278).

${ }^{11}$ Ker je delo v zelo veliki meri sestavljeno iz Sofoklovega besedila, prevzetega iz že obstoječih prevodov, ki se med seboj nemalo razlikujejo tako po interpretaciji nekaterih spornih mest kot po slogu, je Žižkova Antigona v različnih jezikih zelo zanimiva s čisto literarnoteoretičnega vidika: razlike med verzijami v posameznih jezikih namreč ne nastajajo le pri prevajanju Žižkovega besedila, temveč se tudi prevzemajo z različnimi prevodi Sofoklovega besedila.

${ }^{12}$ Žižek, Antigone 26; Žižek, Antigona 30. To delo je pravzaprav nekakšen semicento: krpanka iz mnogih elementov, v katero so všiti tudi izvirni pasusi. 
pasti poenostavljanja in anahronizmov, neizbežni avtorski odmiki pa včasih postavljajo upravičeno vprašanje o mejah istovetnosti literarne teme. Perspektiva, v kateri sodobne adaptacije ali variacije obravnavajo antične teme, je tako neizbežno zamaknjena. $\mathrm{V}$ prispodobi rečeno: razlike med historičnimi, kulturnimi in idejnimi konteksti povzročajo nekakšno paralakso v percepciji resničnosti.

\section{Ultimativna resničnost: izmuzljiva nedvomnost}

To je najbolj zanimivo in problematično (a tudi najbolj razumljivo) pri delih, katerih tema je najgloblja, ki je sploh mogoča: ultimativna resničnost. Čeprav ima morda ta termin danes teološko aromo, ${ }^{13} \mathrm{v}$ resnici označuje temeljno in nepogrešljivo temo vsake odgovorno filozofirajoče misli, torej ne le filozofije $\mathrm{v}$ ožjem pomenu besede, temveč tudi umetniških del z globljim eksistencialnim zajemom. Ta tema nesporno presega literarnovedne okvire: je skrajno široka in notranje divergentna, saj tako rekoč zajema zgodovino filozofije, v nekem smislu pa tudi zgodovino idejnih podlag posameznih kultur in celo civilizacij. Kljub temu pa je ni upravičeno kar odpisati z obzorja literarne hermenevtike, še zlasti ne v primeru umetniških del, za katera so vprašanja po ultimativni resničnosti vitalnega pomena. Med takšna dela sodita Sofoklova in Smoletova Antigona; vsaka na svoj način seveda, a vendar v globokem soglasju, ki ga sicer bogata zgodovina interpretacij ni opazila. To soglasje zadeva koncepcijo (in percepcijo) ultimativne resničnosti: v njej so sile, ki odločilno določajo dogajanje $\mathrm{v}$ dramskem svetu. Te sile po eni strani segajo v svet čisto določno in konkretno (z zahtevo po pokopu Polinejka), po drugi strani pa so eluzivne, izmuzljive, neujemljive in celo prikrite, in to do te mere, da lahko družba in posamezniki (začasno) delujejo povsem mimo njih: vendar je takšno delovanje lahko le začasno in ne more obvladati celotnega prostora človeškega bivanja. To, kar je (najgloblje) resnično (pri Sofoklu božji zakoni, pri Smoletu prava resničnost sveta), ni preprosto in nesporno očitno, zato je lahko tudi začasno družbeno zanikano in eliminirano, bodisi s političnimi ukrepi bodisi s konformistično življenjsko prakso. $\mathrm{V}$ takšni »ideološki« paralaksi se izgubi. S tem pa se izgubi (v obeh dramah bistveno) obeležje resničnosti: njena odprtost. Odprtost resničnosti pa se v najbolj jasni in ostri obliki kaže v človekovi smrtnosti, ki je neizbrisno

${ }^{13} \mathrm{~V}$ tem pomenu ga opredeljuje npr. pomemben filozofsko-teološki zbornik z značilnim naslovom Models of God and Alternative Ultimate Realities (glej Diller in Kasher). 
znamenje njegove individualnosti, $\mathrm{v}$ smrti razodeta enkratnost slehernikove usode je znamenje njegovega ontološkega dostojanstva. Samo $s$ smrtjo se odpira obzorje izven vseh "vidnih" in predstavljivih obzorij, tako rekoč obzorje absolutne nedoločljivosti vsega bivajočega, ki zato ne more biti vključeno v nobeno miselno, zgodovinsko ali kulturno obzorje, je absolutno nezanesljivo in zato izginja iz (javne) zavesti. Toda obenem je ta absolutna nezanesljivost, smrt, tudi edino zanesljivo univerzalno obeležje človeka. Je tisto, kar dopolnjuje sliko vse resničnosti s tem, ko jo odpira na načine neštetih človeških usod. To je vpogled $\mathrm{v}$ ultimativno resničnost, ki pa je slepi pogled, pogled v noč Hada ali pri Smoletu "v deželo drugo" (verz 401), ki je morda sploh nikjer ni. ${ }^{14}$ Ime za to obeležje človeka je pri Sofoklu deinótaton: človek je najbolj nedoumljivo, skrivnostno, in v tem smislu silno bitje. Pri Smoletu sicer človek nima nobenega posebnega imena, vendar je v nekaterih ključnih verzih njegova konfiguracija orisana podobno: je bitje, ki je bistveno zaznamovano z nenehnim iskanjem "druge plati življenja» (verzi 397-401), ${ }^{15}$ prave resničnosti, ki se kaže kot nekakšen negativ družbeno fiksiranega in zatesnjenega obzorja resničnosti (verzi 415-419).

Ključno pa je, da priznavanje ultimativne resničnosti in neukrotljive drugosti življenja, ki se razodeva individualno prek zavesti o lastni smrtnosti, ni nikakršen beg $\mathrm{v}$ onstranstvo in nikakršno abstraktno moraliziranje, kot so zlasti zgodnji kritiki pogosto očitali Smoletovi drami. ${ }^{16}$ Zgodi se tu in zdaj. Ali bolje: mora se zgoditi tu in zdaj. Udejanji se lahko samo v konkretnih družbenih dejanjih, natančneje povedano: v konkretnem opravilu, ki pripada simbolnemu redu družbe. To seveda ne pomeni, da s temi opravili simbolni red "uklene« ultimativno resničnost, jo ujame vase, temveč, nasprotno, da se z njimi sam razklene - torej na neki točki zameji, ne pa tudi scela ukine - in tako ohranja in inten-

${ }^{14}$ To ključno obeležje božanskega povsem ignorira Simon Critchley, ki v svoji sicer osvežujoči in prodorno enostavni knjigi absolutno transcendenco bogov nadomesti z neobvladljivostjo povsem določljivih zgodovinskih dejavnikov in omrežij družbenih institucij, ki določajo človekov položaj. Misliti grško tragedijo na ta način naj bi pomenilo vsaj malo vdihniti pristni atiški zrak (Critchley 74). Dejansko pa je vse, kar po tej "sekularizaciji« neobvladljivih sil ostane, posameznikova podrejenost in nemoč. In nismo več v istem svetu. $S$ takšno sploščitvijo transcendence v neobvladljivo imanenco, kjer je tragedija le še uprizarjanje moralne in politične negotovosti, je zrak atiške tragedije nepovratno izpuhtel.

${ }^{15}$ Te misli o človeku so Antigonine, v drami jih navede Stražnik, in imajo povsem drugačen strukturni položaj kot besede zbora o človeku v prvi zborovi pesmi pri Sofoklu. Antigona jih govori kot svarilo Ismeni, z njimi jo opozarja, kako težaven in nezanesljiv podvig je pokop brata Polinejka. V poznejšem poteku dejanja in v celoti drame pa vendarle dobijo podobno resonanco kot misli iz Sofoklove "pesmi o človeku«.

${ }^{16}$ Glej zlasti Kavčič; Štih, pa tudi Inkret, Esej in "Vprašanje». 
zivira stik z njo. Prek teh opravil se ospredje resničnosti, torej vsakdanje (zgodovinsko, družbeno, politično določeno) življenje, ki ga pragmatično ureja red simbolnega, razpre $\mathrm{v}$ "nesimbolizabilno" ozadje ultimativne resničnosti. To je zlasti za Sofoklovo tragedijo vitalnega pomena. In to je ravno drugače kot, denimo, v vplivni Lacanovi interpretaciji, ki je seveda povsem vpeta v njegovo teorijo subjekta (»ontologijo želje«), po kateri človek je subjekt (še več, Lacan Antigono tam celo uporabi za model te teorije): tam je simbolni red povsem avtonomen glede na realnost (glede na realno oziroma Stvar), povsem odtrgan od nje, da bi lahko tako zagotovil perpetuirano delovanje želje in $s$ tem omogočil trajno življenje človeškemu subjektu želje. ${ }^{17}$ Zakaj v Sofoklovem svetu ni potrebno uvesti simbolnega Drugega, v katerega bi človek projiciral želje in ki bi s svojo lastno "manjkavostjo" konstituiral človekovo libidinalno ekonomijo (De Kesel 221)? Zaradi narave "Stvari«: ultimativna resničnost nevidno žari v človekovem tu in zdaj iz nenapisanih božjih zakonov in pobliskava skozi vprašanja in predstave o posmrtnem življenju, ki je (v nasprotju z nekaterimi sodobnimi interpretacijami) izredno poudarjen in pomemben vidik drame. ${ }^{18} \mathrm{~S}$ svojo neizbrisno in obenem eluzivno prisotnostjo ta resničnost ves čas obenem je in ni tu, ves čas se dotika človekovega sveta v celoti in ga zamejuje, obenem pa ostaja ves čas povsem onstran njega in nedosegljiva. Čeprav je usoda Sofoklove Antigone izjemna, in je to zelo poudarjeno od vsega začetka, pa njen položaj na robu dveh svetov (verzi 559-560 in 850-852), ki ga ponazori zaprtje v skalno ječo oziroma grob, vendarle zelo radikalno in boleče simbolizira splošno conditon humaine.

V Smoletovi Antigoni ni besed o posmrtnem življenju ali pa so povsem nedoločne, priložnostne in mimobežne (verzi 1068-1070), so pa odkrite in velike besede o tem, kaj je svet in kaj je človek; in o tem, kako

\footnotetext{
17 „Simbolni red ne izvira iz realnosti, temveč iz označevalcev, ki so odtrgani od realnega in določajo tisto, čemur pravimo 'realnost' « (De Kesel 224). Ker simbolni red, ki ga v Antigoni predstavlja zakon, temelji na označevalcih, nima trdne (»realne«) osnove, zato ostaja sam zgolj želja po tem, kar naj bi "realiziral«, s tem pa omogoča človeku, subjektu želje, da postane tudi njegov subjekt. V Lacanovi perspektivi Antigona s svojo avtonomnostjo, se pravi s svojo transgresivnostjo, neupoštevanjem zakona po eni strani zrcali (začasno) "avtonomnost« samega zakona, njegovo neodvisnost od realnega, po drugi pa ga sooča z njegovo lastno breztemeljnostjo.

${ }^{18}$ Relevantnost tega vprašanja je razvidna iz logike celotnega dramskega dejanja Antigone in iz številnih izjav, ki brez tega nimajo pravega smisla, povsem neposredno pa Antigona o posmrtnem življenju govori na dveh mestih: verzi 74-76 in 891-899. To zavračanje se večinoma kaže ex silentio, s preprostim ignoriranjem vprašanja, včasih pa se pomen posmrtnosti tudi izrecno zanika, kot to stori Griffith, in sicer z zelo težko razumljivim argumentom, da je za to v besedilu malo podpore (Griffith 40, op. 119).
} 
sta prepletena. To vprašanje je neločljivo povezano s Polineikovim ${ }^{19}$ pokopom: drugače kot pri Sofoklu oblast (katere ideolog ni toliko Kreon kot Teiresias) njegovega trupla ne ukaže izpostaviti v skrunitev pticam in ujedam, temveč zanika njegov obstoj oziroma razglaša, da sploh ne obstaja. Polineikes tako postane večplastni simbol, v katerem je zajet temelj vse človeškosti: $\mathrm{v}$ iskanju njegovega trupla temeljna etična dolžnost, dolžnost pokopa, sovpade z nosilno človekovo željo, željo po samospoznanju, ki je obenem tudi želja spoznati svet. Glas vesti se zliva s klicem duha: temeljno etično opravilo je tudi temeljno intelektualno opravilo. Vendar je to v danih razmerah družbeno prevratno in smrtno nevarno opravilo. Zakaj? Od človekovega odnosa do samega sebe in sveta je odvisno, kako se konstituira družbena podoba resničnosti, torej, kaj v družbi velja za resničnost in kje so njene meje. Od tega je v zadnji analizi odvisno tudi, ali bo družbeno konstituirana resničnost ustrezala ontološki, celotni, "pravi« resničnosti. In kakšna je ta? Od človeka nepostavljena resničnost se $\mathrm{v}$ tej drami razodeva le $\mathrm{v}$ individualnem, samotnem, tveganem, etično motiviranem iskanju kot težko dosegljiv, odprt prostor bivanja. Njena podoba je nezanesljiva, izmuzljiva, nemerljiva, skratka, nepragmatična. Edina privlačna moč resničnosti je $v$ tem, da je pač resničnost. Oblast, ki vidi svojo funkcijo v popolnem obvladovanju vseh območij življenja, takšne resničnosti ne sprejema, temveč jo prireja koordinatam svoje ideologije in preganja vsakogar, ki jih prestopa. Čeprav v pogledih oblastnikov v Smoletovi drami ni težko prepoznati grobe ideologije dialektičnega materializma, gre za veliko širši družbeni pojav: navzven manj agresiven, a idejno podobno radikalen redukcionizem namreč zaznamuje tudi družbe, ki pripadajo sodobni tehnološki civilizaciji; po drugi strani pa se analogna miselnost izraža tudi v ukrepih Sofoklovega Kreonta. Ali je vsaka oblast nujno taka, je drugo vprašanje, vsekakor ne nepomembno, če pomislimo, kako močno je zaposlovalo zgodnje kritike Smoletove Antigone. ${ }^{20}$ V nekaterih ozirih zagotovo ne: država lahko omogoča izpolnjevanje temeljnih etičnih opravil (pokop mrtvih), s primerno organizacijo svojih institucij lahko upošteva tudi tiste vidike resničnosti, ki jih ni mogoče sistemsko nadzirati, so pa pomembni za življenje celotne družbe, čeprav se razkrivajo zlasti v individualnih izkušnjah (npr. doživljanje življenjskega smisla, vprašanje smrtnosti). A je njen domet tu bržkone omejen:

${ }^{19}$ Imena Sofoklovih likov zapisujem in pregibam po eni od danes uveljavljenih različic, ki jih dopušča pravopis, pri Smoletovih pa ohranjam oblike iz izvirnika.

${ }^{20}$ Prim. npr. Predan; Kraigher; Kavčič; Rudolf. Grüna pa je Smoletovo »difamiranje normale« tako vznemirilo, da je svoj odnos izostril do izjave: »Iskreno sovražim to Antigono« (Grün 253). 
odkrivanje resničnosti (etično in intelektualno) je vselej odvisno tudi od individualne bivanjske pobude, ki je svobodna in neizsiljiva in izvira iz posameznikove odločitve. ${ }^{21}$ Ta pobuda pa ne zadeva samo ob zunanjo oviro: ob oblastno represijo, temveč morda še bolj ob notranjo: ob pragmatični hedonizem, ki ga uteleša Haimon in ki ni tuj niti Teiresiu in Kreonu, na koncu pa mu podleže celo Ismena. Oblastni pragmatizem se v nemajhni meri opira ravno na ta praktični in pragmatični hedonizem (izražen $\mathrm{v}$ konformističnem razmišljanju in ravnanju). Posebej pa velja poudariti, da eksistencializem Smoletove Antigone (dolgo časa v tej drži vztraja tudi Ismena, v zadnjem delu drame jo prevzame Paž) ni v kreiranju oziroma postavljanju lastnega bistva, temveč v njegovem odkrivanju: človek eksistira pristno samo v tem odkrivanju. To odkrivanje pa ni pot brez konca, ki bi zahtevala nenehno premeščanje cilja, kar bi bilo mogoče le, če bi ta cilj bil fantazmatičen (kot je lacanovski manjkavi Drugi), torej če bi Polineika v resnici ne bilo, temveč je razpiranje obzorja. Ustrezna podoba odprtosti ultimativne (in s tem tudi celotne, "prave «) resničnosti se namreč zdi obzorje: pokop Polineika ga ne bi zaprl, temveč ravno nasprotno, odprl. Podobe resničnosti, ki jih odkriva individualno iskanje, pa niso v strukturnem, nujnem nasprotju $s$ skupno, družbeno podobo; če v Smoletovih Tebah vlada nepomirljivo nasprotje med skupnim in osebnim prav, med skupnim in osebnim lepim, je to posledica tega, da ljudje "ne slede resnici vesti v svojih prsih « (verzi 1177-1179). ${ }^{22}$ Vprašanje resnice je torej etično vprašanje:

${ }^{21}$ Zato so bila neupravičena pričakovanja in zahteve, da bi morala Antigona predstaviti nov družbeni model, ki bi kot tak lahko prinesel novo kvaliteto družbenega življenja. Pri nekaterih površnejših kritikih se to izraža v odkritem razočaranju in negativnih sodbah, nakazuje pa se tudi v bolj kompleksnih in prodornih analizah (Kos 477; Inkret, Esej 551; Inkret, "Vprašanje« 601), seveda na različne načine in z različnim poudarki. Nasproti temu je treba poudariti: etična in spoznavna pobuda posameznika, ki je tudi znamenje njegove enkratnosti in s tem ontološkega dostojanstva, je integralen, če ne vitalen vidik Smoletove Antigone. S tem je morda motiviran tudi izbor poetične forme: bolj kot psihološka plastičnost likov se zdi pomembno obzorje sveta, ki ga odstira resničnost posameznikove eksistence, in pesniška govorica deluje v tem oziru siloviteje in bolj neposredno. A obenem je slednja vendar tudi psihološko slikovita na čisto svoj način. Kritika, ki jo neživim, značajsko neopredeljenim, retoričnim Smoletovim likom nameni Štih, ni povsem nepodobna svoj čas vplivni kritiki Sofoklovih likov kot golih dramaturških funkcij v študiji Tycha von Wilamowitz-Moellendorffa Die dramatische Technik des Sophokles (484-485).

${ }^{22}$ Celotna dolga Ismenina replika (verzi 1175-1197) je natančen izris problematičnega razmerja med osebno in splošno (družbeno) podobo resničnosti in tudi odgovor na to, zakaj je aktualna splošna podoba »neresnična« (pragmatizem, konformizem, represija oblasti). Te besede Ismena seveda govori še pred svojim zlomom ali konverzijo $\mathrm{v}$ (sicer nekoliko histerično) oportunistko. 
morda zvenijo Ismenine besede o tem, da bi se v etično prebujeni družbi njen prav zlil s skupnim (verz 1180), nerealno, skoraj kot nekakšna somnambulna utvara, vendar pa zagotovo ne izražajo načelnega "zanikanja realnega zgodovinskega sveta in ne po-stavljajo samo-zadostne subjektivitete za temeljno in edino adekvatno možnost sveta" (Inkret, Esej 551). Prej kažejo v drugo smer: na nezadostnost posameznikovega iskanja, ki mu preostaja upati proti upanju, zato da bi v svetu ne ugasnilo še tisto nekaj resnice, do katere se mu je dano prikopati.

\section{Dramaturške navezave in kontrasti}

Tema ultimativne resničnosti je $\mathrm{v}$ dramskem delu navadno izražena skozi druge, ožje, bolj oprijemljive teme, h katerim se rade odklonijo perspektivično zožene replike. Literarna zgodovina ali teatrologija se ponavadi nagiblje $\mathrm{k}$ iskanju vzporednic med posameznimi dramami na formalni, jezikovni, tematski ravni in $\mathrm{v}$ realnih zgodovinskih okoliščinah nastanka. Tam jih je namreč sorazmerno preprosto opaziti in objektivno demonstrirati. S tem seveda nočem reči, da je to kaj trivialnega, da te ravni ali plasti dramskega besedila niso pomembne za konstitucijo posamezne drame v celoti, nasprotno: prav te so "živo meso" vsakega besedila, po katerem slednje sploh je umetnina in se lahko na umetniški način dotika ultimativne resničnosti. Kar je problematično, je samo skušnjava interpreta, da z njimi scela zameji svoje obzorje, kadar gre za dela, ki so vitalno povezana z vprašanji zadnje resničnosti. Seveda pa ni nujno, da interpret tej skušnjavi podleže: intertekstualnost lahko raziskuje tudi tako, da se ne ujame povsem $\mathrm{v}$ mrežo horizontalnih literarnozgodovinskih razmerij. Vsekakor pa interetekstualne povezave ne širijo in poglabljajo zgolj pomenske razsežnosti dela, temveč tudi idejno in naposled celo doživljajsko: po načelih zgodovinskega navezovanja, prisvajanja in kontrastiranja se bogati tako intelektualni kot umetniški potencial besedila.

Neposreden vpliv Anouilhove Antigone na Smoletovo »je nedvomen, kakor je razvidno iz pričevanj, člankov, kritiških in literarnozgodovinskih odmevov" (Schmidt, Dominik Smole. Zbrano delo. Druga knjiga 176). Zares sistematično in nadrobno pa ta vpliv - vsaj po mojem vedenju - žal še ni bil raziskan. Tem bolj pa to velja za razmerje s Sofoklovo istoimensko tragedijo. Seveda kritiki in literarni zgodovinarji v študijah o Smoletu omenjajo Sofoklovo tragedijo, vendar izrazito mimobežno in površno, $v$ glavnem povzemajo splošna historična dejstva, izpostavljajo skupno idejo upora oblasti in morda še oddaljenost in drugačnost antičnega sveta. Dejansko pa je tudi med Sofoklovo in Smoletovo 
Antigono vrsta povsem očitnih vzporednic in kontrastov (modifikacij) na različnih ravneh (od temeljnih dramaturških prijemov in kontrastiranja značajev do premeščanja in parodije posameznih izjav), kar vse potrjuje uvodoma navedene Smoletove besede o pomenu Sofoklove drame zanj. Predstavitev le-teh bi presegla okvire te razprave, poleg tega pa to tudi ni njen pravi namen. Vsekakor pa gre za izzivalno in obetavno temo posebne komparativistične raziskave. Tu bom nanizal samo najzanimivejše primere.

Skoraj odveč je omenjati najbolj vidno in izvirno inovacijo: odsotnost naslovne junakinje z odra, ki s posebno intenzivnostjo določa vse odrsko dogajanje. Po pričevanju Smoletovega tesnega prijatelja Tarasa Kermaunerja je bila to »edinstvena zamisel« sociologa Veljka Rusa, po kateri je temeljito spremenil prvotno verzijo, kjer je Antigona "samovšečno in moralistično docirala vsenaokrog", in jo napravil za odsotno navzoč lik. Kermaunerjeve lastne pripombe in pripombe njegove žene Alenke Goljevšček pa so po tem pričevanju močno pripomogle tudi k preoblikovanju lika Kreonta (Kermauner 175).Ta sprememba je seveda neizbežno prinesla radikalno preoblikovanje Sofoklove dramaturgije v celoti. Zelo očitno se Smoletova ustvarjalna navezava kaže v scela drugačni dramaturški teži in značaju vseh večjih likov: Kreona, ${ }^{23}$ Tejresia in Haimona, in v uvedbi novih; Paža, ki dobi v nekem smislu celo ključno vlogo. ${ }^{24}$ Premeščanja in parodične zasuke najdemo tudi na mikroravni: Kreontove blasfemične besede (pri Sofoklu npr. verzi 560-561 in 777-780) pri Smoletu izgovarja Teiresias (npr. verzi 1137-1139); če je pri Sofoklu Kreont tisti, ki prezirljivo razvrednoti Hajmonovo in Antigonino zvezo s hedonističnim argumentom in reducira ljubezen na fizično spolnost (verz 569), je pri Smoletu tak kar Haimonov lastni pogled (verz 513)..$^{25}$

${ }^{23}$ Smoletov Kreon zagotovo kaže največ Anouilhovega vpliva od vseh Smoletovih likov, tako v celoti, kot v nekaterih pasusih (prim. zlasti verze 623-652), a vendar ima tudi povsem svojo specifično fiziognomijo, prim. denimo veliki monolog o zrcalnih sanjah (verzi 1256-1342).

${ }^{24}$ Ta lik je zagotovo prevzel od Anouilha, a ga je močno razširil, mu dal povsem drugačno, bistveno pomembnejšo vlogo. Iz zgolj nakazane možnosti likvidacije nepazljivih stražnikov pri Anoulihu razvije Smole motiv Paževega dejanskega umora po ukazu oblasti, to dejanje pa Paža potisne na pot očitne etične preobrazbe, kar v svetu Smoletove Antigone pomeni pot ohranjanja resnice o Polineiku in pot odkrivanja samega sebe.

${ }^{25}$ Haimon sicer skozi celotno igro kaže frivolni hedonistični odnos (kljub občasnim pomislekom o lastni votlosti, npr. verz 1748), zlasti kar zadeva erotiko (prim. npr. verzi 499-513; posebej manifestativno v verzih 1035-1056). Tudi njegove skoraj histerične reakcije v drugem delu drame (verzi 1722-1725 in 1761-1780) so očitno samo izraz te drže, soočene $z$ lastno praznoto. 
Posebna tema je seveda razširitev in dinamiziranje Antigoninega in Ismeninega razmerja, ki se razvija povsem drugače kot pri Sofoklu. Njuni vlogi v začetnem prizoru, kjer se odločata za kljubovalni pokop brata (pri Sofoklu verzi 1-99) sta tu ravno obrnjeni: Antigona opozarja na težavnost tega podviga, Ismena pa ji očita brezsrčnost in se polna goreče odločenosti zaroti, da bo sama opravila ta podvig; šele ta njena drža v skoraj mističnem trenutku Antigono etično prebudi v iskalko resnice (verzi 395-419). V velikem delu drame, pred svojim oportunističnim zlomom, je Ismena tista, ki zagovarja Antigonino stvar (pri Sofoklu se Ismena "spreobrne« in pridruži sestri, ko je ta že obsojena na smrt, verzi 536-537 in nasl.). Navsezadnje pa je Smole (verzi 679-680) položil njej v usta - le malce spremenjene - morda najslavnejšse Antigonine besede o tem, zakaj je na svetu (prim. Sofokles verz 523):

Zaradi ljubezni in miru sem tu,

jaz prva dvigam roko zoper zlo.

V Smoletovi drami imajo izredno pomembno vlogo poročila: velik del dogajanja - vsa Antigonina dejavnost in pravzaprav vse njeno življenje - poteka izven odrske resničnosti v ožjem pomenu besede; vse, kar izvemo o tem, zvemo iz pripovedi drugih likov (Stražarja, Ismene, Paža). To je seveda nujna posledica koncepcije Antigone kot odsotno prisotnega lika, in bržčas je le koincidenca, da je Smole tako uporabil eno temeljnih orodij vse grške tragedije: poročilo. Po (nenapisani) konvenciji posebej grozovita ali težko upodobljiva dejanja (smrt, samomor) v Dionizovem gledališču nikoli niso bila prikazana, temveč so o njih dramski liki le poročali. Tako se je iluzionistični prostor resničnosti razširil onstran meja vidnega, in v nekem smislu postal še bolj realističen: resničnost ni le to, kar je vidno, in ne le to, kar je tu in sedaj, temveč ima svoje globoko nevidno ozadje, ki sega onkraj običajnih predstav o prostoru in času. Iz cele vrste tragedij veje to občutje, ali, rečeno v duhu atenske tragiške institucije, prihaja ta opomin. In če Smoletova Antigona govori o čem, govori prav o tem.

Vsekakor je zanimivo tudi, da je Smole ohranil zbor, ta izvorni element tragedije, in ga na izviren način umestil v svojo poetično kompozicijo: ${ }^{26} \mathrm{v}$ uvodnih besedah (verzi 4-20) se bržčas kaže pojmovanje tragiškega zbora kot izvenčasovnega lika, ki z višjega razgledišča komentira dogajanje $\mathrm{v}$ drami:

\footnotetext{
${ }^{26}$ Prim. Smole, »Pismo«.
} 
Še mi tebanski starci, čeprav do tal upognjenih teles, zlomljenih kosti in s srci, ki teptala so jih vsa stoletja, še mi, ki nas le silna teža ponavljanja je ohranila za žive priče slehernega časa, spet glave dvigamo.

To po izvoru romantično pojmovanje je bilo v času nastanka Smoletove Antigone tudi v specializirani literarni zgodovini povsem v veljavi. Podobno še Heidegger v Hölderlins Hymne "Der Ister " meni, da lahko tebanski starci v t. i. pesmi o človeku (verzi 332-375) govorijo o človekovem »Unheimischsein« samo zato, ker imajo poseben status (glej Withy, Heidegger 175-176). Šele klasični filolog Gerhard Müller je z nadrobno analizo Filokteta pokazal, da je Sofoklov zbor tudi dramski lik z vsemi človeškimi značilnostmi in omejenostmi drugih likov (glej Müller). Stvarna resničnost v drami je časovno neopredeljiva, ne moremo reči anahronistična, saj Smoletov namen ni prikazati grško antično družbo (mimogrede, tudi Sofokles slika za svoj čas "sivo davnino" mita): ${ }^{27}$ liki nosijo seveda grška mitološka imena, a potem je tu še Paž (služba iz drugih zgodovinskih časov), Eteokles in Polinejkes si poženeta kroglo v glavo, nevidni srednji napadalec je zagnal zemljo v mrežo drugih zvezd (primera iz sveta novodobnega športa, nogometa) ...

Nenazadnje pa je prav posebej tesna vez s Sofoklovo dramo pesniška oblika, ki jo je Smole po lastnih besedah pri tej temi moral uporabiti in ki predstavlja sama po sebi posebno odliko njegove mojstrovine.

\section{Odsotna prisotnost ultimativne resničnosti}

Zgoraj navedene vzporednice verjetno ponujajo motiv za natančnejše intertekstualno branje. Toda tisto, kar je poglavitna tema te razprave, je primer "globinske analogije « med dvema dramama, ki je tako tematska (v smislu vprašanj ultimativne resničnosti) kot dramaturška (v smislu motivacije). Odločilno vlogo v obeh dramah ima to, kar je odsotno: kar se v drami sploh ne pojavi kot lik. Pri Sofoklu so to bogovi, pri Smoletu pa sta odsotna Polinejkovo truplo in naslovna junakinja, in sicer do samega konca drame, ko se njena odsotnost nekako prelije v Paževo. Paž tedaj pobegne, izgine z obzorja dramske resničnosti: čeprav se drama tedaj sklene in dramska resničnost na ta način ugasne, nastane

${ }^{27}$ Tudi tu je zelo verjeten vpliv Anouilhove Antigone, ki pa se zdi bolj locirana v sodobni svet, še posebej glede na materialno resničnost, kljub nekaterim, pravzaprav redkim, potezam starodavnega sveta (npr. Polinejkovo in Eteoklovo truplo izmaliči težka argejska konjenica). 
vtis, da se je Paž izmaknil iz dimenzij zamejenega sveta, ki jih je pred gledalci razgrinjalo dramsko dejanje in ki so jo tudi nekatere replike nekaterih likov - Tejresia, Kreonta in Haimona - posredno označevale kot edino pravo, vredno, resnično resničnost. Nasprotno pa se je Ismena pomaknila s senčne strani na meji širše, ultimativne resničnosti v »oprijemljivi« svet.

Pri Sofoklu je to delovanje odsotnega božjega na različne načine in $\mathrm{v}$ različni meri značilno za vse ohranjene tragedije. Najbolj značilna oblika njegove odsotne prisotnosti so prerokbe, ki zaznamujejo dejanje vseh dram. V Ajantu (verzi 748-783) sel poroča o napovedi vidca Kalhanta: Ajant bo umrl ravno na dan, ko se dogaja tragedija. V Trahinkah je cela vrsta prerokb, katerih uresničenje v nepričakovani obliki prikazuje dramsko dejanje. Kralj Ojdip je detektivska samoraziskava naslovnega lika, v kateri protagonist odkrije celo to, da so se zanj usodne prerokbe že zgodile. V Elektri Orest izvrši maščevanje nad materjo po Apolonovem naročilu. V Filoktetu mora naslovni lik proti svoji volji z nenaseljenega otoka Lemnosa pred Trojo, ker brez njega in njegovega loka Troja ne bo padla: Neoptolem sporoči, da je takšna preroška napoved vidca Helena (verzi 1437-1447). Ostareli Ojdip prispe v Kolon, ker mu je Apolon prerokoval, da bo tam našel oddih od muk življenja (verzi 84-95). Samo v Antigoni ni nobene takšne prerokbe; imajo pa zato v njej analogno vlogo nenapisani zakoni, ki pa jih - in to je nadvse pomembno - ne oznani preročišče, temveč Antigona, ki zato ni posebej "pooblaščena" (ne velja za vidkinjo), temveč to počne na lastno pest in zaradi te »božje stvari« celo izgubi življenje (ali pa je vsaj potisnjena v položaj, ko si ga v obupu sama vzame). V Sofoklovih dramah so vse božje napovedi, ki so na neki način tudi zapovedi, nekako potisnjene v ozadje in na neki način skorajda odsotne; bodisi so mnogim likom neznane, bodisi jih napačno razlagajo, včasih jih celo prezirajo (Ajant) ali nočejo sprejeti (Filoktet) ali pa se jim posmehujejo (Jokasta); seveda pa se vedno izpolnijo, z eksplicitnim božanskim posredovanjem ali brez njega.

V Sofoklovi Antigoni bogovi torej ne nastopijo, vendar se vse v drami zgodi zaradi njih. Njihova avtoriteta ni sporna, a je prav zato, ker so odsotni, nejasna in eluzivna njihova volja: to odpira prostor za različne interpretacije in predvsem sproži vrsto usodnih konfliktov med liki; temeljna antropološka, etična, politična, celo spolna vprašanja vznikajo v živem duktusu dramskega dejanja, ki ima katastrofalne posledice za posamezne like, zlasti pa za celotno vladarjevo družino. Polis, država, je morda po takšnem delovanju odsotnih bogov (predvsem prek svojega "glasnika« Tejerezija) rešena - tako se ob koncu drame vsaj nakazuje, a 
ni jasno izraženo. $Z$ vso radikalnostjo pa se odpira vprašanje negotovega posmrtnega življenja likov, o čemer Antigona eksplicitno govori na več mestih, in ki je tudi v prvi pesmi zbora, t. i. pesmi o človeku, jasno opisano kot človekova meja - in s tem tudi njegovo bistveno določilo. $S$ tem vprašanjem se spremeni perspektiva razumevanja človeka. Od dosežkov človeške vrste, ki se ohranjajo in množijo skozi rodove, se premaknemo $\mathrm{k}$ individualni usodi: paradoksno šele $\mathrm{v}$ njej človek sreča tisto, kar je najsplošnejše, najbolj zanesljivo, a obenem tudi najbolj nedoumljivo, pravzaprav absolutno nedoumljivo, ker na paradoksen način zadeva ne le njega, temveč vse, kar je. Zarisuje torej neprestopno mejo, za katero je ultimativna resničnost (človek, deinótaton - najsposobnejše bitje, tako postane tudi najskrivnostnejše, najosupljivejše bitje). V besedah o neizbežnosti smrti (verzi 361-362) je uporabljen futur (epáxetai): človek "nikoli ne bo našel sredstva, da bi ubežal Hadu. «V kontekstu pesmi to implicira tako njegovo nenehno prizadevanje za to kot tudi neuspešnost tega prizadevanja in tako začrtuje bistvo usode slehernika.

Vprašanje smrti, vzeto dokončno zares, je za človeka najgloblje ontološko vprašanje, vprašanje ultimativne resničnosti. Etična dimenzija Sofoklove drame, ki jo odpira vprašanje Polinejkovega pokopa z vsemi političnimi in drugimi družbenimi razsežnostmi, tega vprašanja ne prekrije. Nasprotno, iz njega se napaja in dobiva svojo bistveno relevantnost. Naj z drugimi besedami obnovimo, kar je bilo povedano že zgoraj: radikalno drugo (skrivnost smrti in zakoni bogov) je na neki način povsem odsotno, omogoča svoje lastno ignoriranje, po drugi strani pa je ves čas tu kot nevidni temelj, ki določa vse bivajoče in vse njegovo dogajanje. Obenem pa prav s tako odsotno prisotnostjo daje mero pristnosti človeškemu bivanju: ne prek mehanizma želje, temveč prek lastne nedoumnosti in odprtosti lahko človek spoznava to skrivnost (in lastno potopljenost vanjo). Zato pa ne zadostuje, če ultimativno resničnost tematiziramo kot nemo, slepo nasprotje slehernega reda (kot nesimbolizabilno realno, Stvar), temveč se prej kaže kot nekakšen deloma razviden red, katerega korenine pa ostajajo človeku vsaj za časa njegovega življenja ${ }^{28}$ - nevidne. Kot tisto, kar zgoščeno povzema grška sintagma métron kai mystérion: skrivnostni red.

V Smoletovi drami in njegovem svetu bogov v pravem pomenu besede - torej v pomenu sil, ki kot pri Sofoklu vladajo ultimativni resničnosti - ni. ${ }^{29}$ Ali bi bila sploh mogoča večja distanca od Sofoklovega

${ }^{28}$ To zelo jasno izražajo ene zadnjih besed Sofoklove Antigone, verzi 925-928.

${ }^{29}$ Beseda »bogovi« se sicer v drami večkrat pojavi, vendar sploh nima primerljivega pomena s tem, kar označuje pri Sofoklu. Včasih se zdi komaj kaj več kot medmet (verza 751 in 1493), včasih del pomensko izpraznjene fraze (verza 1692 in 1696); 
sveta? Kar je tu odsotno, je človek: človekovo truplo. Le-to pa ni odsotno samo v smislu nečesa, česar ni tu (kar torej je nekje drugje: ab-esse, ap-eînai), temveč je zavestno, hote potisnjeno na ali že čez rob vsakršnega obstoja. ${ }^{30} \mathrm{Na}$ podoben način je odsotna Antigona, ta, ki ne verjame, da ga ni, ki ga išče navkljub očitkom, da išče nekaj, česar ni in da v svoji blaznosti to pravzaprav "ustvarja«. Je socialno/odrsko mrtva. Podobno zase trdi Sofoklova Antigona, ki zatrjuje, da je njena duša že davno mrtva (verz 561), vendar po drugi strani pravi, da bo morala v zagrobnem svetu živeti neprimerno dlje kot na zgornjem; pozneje $\mathrm{v}$ paroksizmu bolečine, ko jo vodijo v kamnito ječo-grob, pa toži, da ne pripada nobenemu svetu, ne živim, ne mrtvim (verzi 850 in nasl.). Iz tega medprostorja, "neprostora « potem pobegne s samomorom. $\mathrm{Na}$ ta način je izvor ali težišče dramskega dogajanja postavljeno v odsotno: ali ni to očitna sugestija, da je tam tudi nevidno težišče vse resničnosti, kot jo uprizarja Smoletova drama? Vendar njegova Antigona tudi sama noče živeti v t. i. resničnem svetu (pragmatičnem svetu "moralne večine«), kakršnega opisuje Tejresias (verzi 321-327):

Svet je to, kar je,

kar vidiš, čutiš in otiplješ s prsti.

Poleg tega, reči hočem, mimo tega, pravzaprav ...

nad tem, je svet vse, kar je skladno $\mathrm{z}$ našo pametjo, normalno, bi dejal, spodobno ter urejeno nam $\mathrm{v}$ korist.

Lahko bi rekel: svet je družba. Ne: svet je človek. Še bolje: svet sem jaz.

Antigona vseskozi zavrača takšen svet, ki je kljub deklarirani »skupnosti« in vključujočnosti v bistvu privatističen (verzi 1966-1968):

Ti nisi vse - ga slišite, mi pravi - in svet

ni tvoje dopolnilo. Kako si majhna in nebogljena

ob tem, kar je bilo, kar je in bo.

Njena vera, o kateri govori Stražnik, ga tako rekoč neposredno zanika (verzi 415-419):

komajda kdaj nakazuje kaj več (verz 1562), a se iz takšne omembe ne razvije nikakršna tema. Poročilo glasnika, v katerem bogovi sporočajo, da Polineika ni (verz 2196), seveda zarisuje izredno važno vprašanje, ki pa izzveni v prazno: bržčas si je treba predstavljati delfsko preročišče kot religiozno institucijo oblasti, katere funkcija ni stik z ultimativno resničnostjo, temveč ravno nasprotno, preprečevanje tega stika.

${ }^{30}$ To je pravzaprav Teiresiasova »mantra«: prim. verze 931, 1867, 1906 in 2010. 
Nisem le, kar sem, in svet ni samo to, kar vidim, čutim in otipljem.

Zakoni drugi vodijo življenje, zato sem tu, da jih spoznam, zato sem tu, da zvem, kdo sem.

Ta svet $\mathrm{v}$ odsotnost potisnjene resničnosti, zanikani svet, katerega slutnja poganja vse dejanje drame, je vendarle predvsem odprt svet. Njegova privlačnost in moč je, kot že rečeno, prav v odprtosti: ta je znamenje resničnosti, ki je na svoj način močnejša od vsega. Odprtost, ki je obenem zaveza in svoboda. Živeti v tej odprtosti pomeni živeti etično. Vendar ne le, da to ni preprosto, temveč je neznosno težko. Zakaj? Zato, ker odprta resničnost kljub svoji navidezni nemoči razkriva, da je pragmatično obvladani in osmišljeni svet iluzija. Ljudje postajajo oportunisti in konformisti predvsem zaradi iskanja ugodja, še zlasti čutnega ugodja, socialne varnosti in miru. Sofoklovi Tebanci molčijo iz strahu pred Kreontovim tiranstvom (verzi 504-505 in 690-691), Smoletovi pa "žive, se vesele, kopičijo užitke / in prav neradi slišijo za smrt", najboljše jim je takrat, ko jih nihče ne vznemirja (verzi 1207-1209). Slutnja resničnosti onkraj koordinat pragmatičnega obstoja kljuva prav v njihovo največje ugodje: v gotovost njihovega omejenega obstoja, v njihov samozadostni, zakrknjeni hedonizem. Čeprav tiha, skoraj nezaznavna, ta slutnja razpira meje domnevno objektivnega sveta in mu spodmika temelj. To sproža različne oblike zavračanja: Antigona je v resnici slepa, če pa vidi, vidi drugačen svet, svet, v katerem Polineik je, ni pa "normalnih" Tebancev, "normalnih" ljudi. "Jaz ne vzdržim tega, / da nekaj je, kjer mene ni, "plastično izrazi stisko tega $\mathrm{v}$ jedru nasilnega subjektivizma Ismena (glej verze 1810-1814). Od tod njen notranji kaos, njena skoraj panična zahteva po znanstvenem dokazu, da Polineika ni (verzi 1923-1948), a tudi pomisleki, da morda Antigona vendarle ni blazna in ima prav (verzi 2056-2073); od tod Haimonov histerični klic, da je treba Polineika znova ubiti (verz 1907), želja, da bi spet našel red, mir, radost in svobodo (verzi 1871-1873 in 1883); in od tod tudi Teiresiev cinično pragmatični nihilizem (verzi 2035-2046).

Podobno kot Sofoklova junakinja nima jasnega vedenja o posmrtnem življenju (verzi 897-902), tudi Smoletova ne more vedeti, kakšna je skrivnostna dežela, kjer je Polineik. Kar ve, je le to, da je daleč od "tega sveta«, še več: da je »druga plat življenja» (verzi 397-401): 
Zelo je dolga pot do brata, čez ostro trnje vodi in čez hude kamne. In cilj? Kdo ve, če sploh je trdni in dokončni cilj?

Daleč čez črto tega mesta kaže kažipot,

V deželo drugo, na drugo plat življenja.

Kakor je iz Sofoklove "pesmi o človeku" (verzi 332-375) jasno, da se ultimativni resničnosti življenja, smrti, človek približa le sam, mora tudi v Smoletovo drugo deželo, na drugo plat življenja, človek sam. To je Paževo prelomno spoznanje, potem ko se obrne k tisti plati, Ismena pa se obrne v drugo smer in ga zapusti (verzi 1660-1662):

Zbogom, gospa. Oditi moram torej sam.

Zmeraj sem vedel, da moram sam.

Vse moram brez pomoči in sam, le v tem je odkupnina.

In ko tik pred koncem Antigono usmrtijo (v zaodrju), se tudi požene tja, a tokrat pokliče še druge - morda za to, da bi vztrajali vsak na svoji poti k resničnosti v nevidnem občestvu samot (verzi 2239-2240):

Za njo! O ponižani, šibki, v temo zroči!

Za njo, z njeno vero in po njeni poti!

Po tej poti, tako lahko sklepamo iz zadnjih besed drame (izreče jih Teiresias), je tudi ušel. Zdi se torej, da se ta pot ne konča pri Polineiku, a tudi ne more mimo njega. ${ }^{31}$ Koga pa doseže Pažev klic, o tem igra molči.

\section{LITERATURA}

Anderson, Michael J. "Myth«. A Companion to Greek Tragedy. Ur. Justina Gregory. Malden, MA, Oxford, Victoria: Balckwell Publishing, 2005. 121-135.

Critchley, Simon. Tragedy, the Greeks, and Us. New York, NY: Pantheon Books, 2019. Croally, Neil. "Tragedy's Teaching". A Companion to Greek Tragedy. Ur. Justina Gregory. Malden, MA, Oxford, Victoria: Balckwell Publishing, 2005. 55-70.

Csapo, Eric, in William J. Slater. The Context of Ancient Drama. Ann Arbor, MI: The Universtiy of Michigan Press, 1994.

${ }^{31}$ Prim. Ismenino repliko (verzi 2056-2073), sestavljeno iz vrste samih vprašanj, ki ponovno postavljajo pod vprašaj njeno novo, oportunistično življenjsko usmeritev: $\mathrm{v}$ njih se sprašuje o tem, ali ni morda pot do prave človeškosti etično odgovorno prodiranje v globljo resničnost, pot k tistemu, »kar raste s svežim cvetom / in iz zmeraj nove zemlje« (verzi 2066-2067, poudarek je moj). 
De Kesel, Marc. Eros and Ethics. Reading Jacques Lacan's Seminar VII. Albany, NY: State University of New York Press, 2009.

Diller, Jeanine, in Asa Kasher, ur. Models of God and Alternative Ultimate Realities. Dordrecht, Heidelberg, New York, NY, London: Springer, 2013.

Griffith, Mark, izd. Sophocles. Antigone. Cambridge: Cambridge University Press, 1999.

Grün, Herbert. »Mariborska Drama. Prerojenje zavoda?«. Nova obzorja 5-6 (1961): 250-255 (=Schmidt, Dominik Smole. Zbrano delo. Druga knjiga 244-254).

Halliwell, Stephen. "Learning from Suffering". A Companion to Greek Tragedy. Ur. Justina Gregory. Malden, MA, Oxford, Victoria: Balckwell Publishing, 2005. 392-412.

Heidegger, Martin. Gesamtausgabe 53: Hölderlins Hymne "Der Ister«. Frankfurt ob Majni: Vittorio Klostermann, 1993.

Heidegger, Martin. Uvodv metafiziko. Prev. Aleš Košar. Ljubljana: Slovenska matica, 1995.

Inkret, Andrej. Esej o dramah Dominika Smoleta. Maribor: Založba obzorja, 1968. (=Schmidt, Dominik Smole. Zbrano delo. Druga knjiga 549-551).

Inkret, Andrej. "Vprašanje o odsotni Antigoni«. Primerjalna književnost 1 (1981): 12-15 (=Schmidt, Dominik Smole. Zbrano delo. Druga knjiga 600-602).

Kavčič, Vladimir. "Abstraktnost 1960«, Naši razgledi 25. 2. 1961: 4 (=Schmidt, Dominik Smole. Zbrano delo. Druga knjiga 498-502).

Kermauner, Taras. Perspektivovci. Ljubljana: Znanstveno in publicistično središče, 1995. (=Schmidt, Dominik Smole. Zbrano delo. Druga knjiga 175-176).

Kos, Janko. "Resnica današnje drame, III". Perspektive 8 (1961): 1042-1052 (=Schmidt, Dominik Smole. Zbrano delo. Druga knjiga 462-477).

Kraigher, Dragana. »Končna postaja - osveščenost!«. Tribuna 11. 5. 1960: 5 (=Schmidt, Dominik Smole. Zbrano delo. Druga knjiga 222-225).

Lacan, Jacques. Etika psihoanalize. Ljubljana: Delavska enotnost, 1988.

Miller, Paul A. „Lacan's Antigone: the Sublime Object and the Ethics of Interpretation". Phoenix 61.1/2 (2007): 1-14.

Müller, Gerhard. „Chor und Handlung bei den griechischen Tragikern«. Sophokles. Ur. Hans Diller. Darmstadt: Wissenschaftliche Buchgesellschaft, 1967. $212-238$.

Nagy, Gregory. "The Earliest Phases in the Reception of the Homeric Hymns". The Homeric Hymns. Interpretative Essays. Ur. Andrew Faulkner. Oxford: Oxford University Press, 2011. 280-333.

Popovič, Anton. "Aspects of Metatext«. Canadian Review of Comparative Literature 3 (1976): 225-235.

Predan,Vasja. "Smoletova Antigona«. Ljubljanski dnevnik 12. 4. 1960: 3 (=Schmidt, Dominik Smole. Zbrano delo. Druga knjiga 214-217).

Rudolf, Branko. "Smoletova Antigona«, Delo 9. 11. 1960: 6 (=Schmidt, Dominik Smole. Zbrano delo. Druga knjiga 238-240).

Schmidt, Goran, ur. Dominik Smole. Zbrano delo. Druga knjiga. Ljubljana: Založba ZRC, 2009.

Schmidt, Goran, ur. Dominik Smole. Zbrano delo. Peta knjiga. Ljubljana: Založba ZRC, 2010.

Smole, Dominik. "Nevezan pogovor z avtorjem Antigone«. Nepodpisano; najverjetneje je spraševal Lojze Filipič. Gledališki list Drame SNG v Ljubljani 3 (1960/61): 74-76 (=Schmidt, Dominik Smole. Zbrano delo. Peta knjiga 249-253). 
Smole, Dominik. "Antigone pobjeđuju uvijek i uprkos svemu. Pogovor vodil Feliks Pašić«. Borba 12. 1. 1964: 10 (=Schmidt, Dominik Smole. Zbrano delo. Peta knjiga 253-258).

Smole, Dominik. "Pismo Zorku Simčiču" (=Schmidt, Dominik Smole. Zbrano delo. Peta knjiga 353-358).

Sommerstein, Alan H. Aeschylean Tragedy. London: Durkworth, 2010.

Steiner, George. Antigones. The Antigone Myth in Western Literature, Art and Thought. Oxford: Oxford University Press, 1984.

Štih, Bojan. »Kreona ali Antigona«. Naša sodobnost 6 (1961): 557-565 (=Schmidt, Dominik Smole. Zbrano delo. Druga knjiga 478-490).

Wilamowitz-Moellendorff, Tycho J. W. von. Die dramatische Technik des Sophokles. Berlin: Weidmann, 1917.

Withy, Katherine. Heidegger on Being Uncanny. Cambridge, MA, London: Harvard University Press, 2015.

Žižek, Slavoj. Antigona. Ljubljana: Društvo za teoretsko psihoanalizo, 2015.

Žižek, Slavoj. Antigone. London, Oxford, New York, NY, New Delhi, Sydney: Bloomsbury, 2016.

\section{Power of the Absent: Elusiveness of the Real in the Two Antigones}

Keywords: Slovenian drama / Greek tragedy / Sophocles / Smole, Dominik / Antigone / literary influences / intertextuality / ethics / ultimative reality

Sophocles's Antigone famously never introduces gods on stage (even in the form of prophecy), and yet everything happens through their agency. The authority of the gods is never called into question; their absence, however, makes their will elusive and unclear, which enables Antigone and Creon to interpret it in completely different ways and causes their fatal conflict. When Teiresias reveals that Creon is wrong, it is too late for Antigone, who dies because she remains true to her (correct) understanding of the divine will (law), although unsupported by any, either divine or human, external authority. In Dominik Smole's Antigone, by contrast, it is the heroine herself who is absent until the very end of the play, when, after her death, the Pageboy takes over her role. Smole's radical innovation persistently draws the reader's (audience's) attention to the background of the dramatic action, to the invisible reality beyond the stage: to the forbidden region outside society where the key questions of historical truth and of the quintessence of human existence arise. There is a striking analogy between the two Antigones, both in terms of dramaturgy and representation of reality: both plays present the 
ultimate reality (gods in Sophocles, true human identity in Smole) as hidden yet effective. This ultimate reality reveals itself as a dark horizon and keeps the reality of human existence open. In addition to the central theme, the paper discusses a number of questions about the motivation for reinterpreting canonical texts.

1.01 Izvirni znanstveni članek / Original scientific article

UDK 82.091

821.14'02.09Sophocles

821.163.6.09Smole D.

D0I: https://doi.org/10.3986/pkn.v44.i1.03 